\title{
Characterization of Algerian kaolins for utilization as a raw material in electrical insulators
}

\section{(Caracterização de caulins argelinos para utilização como matéria-prima em isolantes elétricos)}

\author{
M. Laraba ${ }^{1,2 *}$ \\ ${ }^{1}$ University of Tebessa, Mining and Geothechnolgy Department, Mining Laboratory, Algeria \\ ${ }^{2}$ University of Jijel, Process Engineering Department, LIME Laboratory, Algeria
}

\begin{abstract}
The aim of this investigation was to characterize three samples of kaolin (DD1, DD2 and DD3) collected from Djebel Debbagh deposit (East of Algeria) to be used in electrical porcelain insulators. Grain-size analysis, X-ray fluorescence, X-ray diffraction, scanning electron microscopy and thermal analysis (TG-DTA) were performed. Each sample was mixed with feldspar and silica to obtain three porcelain formulations. The obtained results indicated that the three kaolins were composed by kaolinite and halloysite with variable contents of $\mathrm{MnO}$ and $\mathrm{Fe}_{2} \mathrm{O}_{3}$ as associated impurities. It was found that the DD1 was the appropriate kaolin as raw material for making the high-voltage electrical insulator which had the highest electrical and mechanical properties (dielectric strength, bending strength and bulk density), while DD2 and DD3 were less suitable due to their lower properties caused by the presence of impurities which must be removed.
\end{abstract}

Keywords: Djebel Debbagh kaolin, electrical insulators, dielectric strength, bending strength.

Resumo

O objetivo desta investigação foi caracterizar três amostras de caulim (DD1, DD2 e DD3) coletadas do depósito de Djebel Debbagh (leste da Argélia) para serem utilizadas em isoladores elétricos de porcelana. Análise granulométrica, fluorescência de raios $X$, difração de raios $X$, microscopia eletrônica de varredura e análise térmica (TG-ATD) foram realizadas. Cada amostra foi misturada com feldspato e sílica para obter três formulações de porcelana. Os resultados obtidos indicaram que os três caulins foram compostos por caulinita e haloisita com teores variáveis de $\mathrm{MnO}$ e $\mathrm{Fe}_{2} \mathrm{O}_{3}$ como impurezas associadas. Verificou-se que o DD1 foi o caulim adequado como matéria-prima para a fabricação do isolante elétrico de alta tensão que apresentou as maiores propriedades elétricas e mecânicas (rigidez dielétrica, resistência à flexão e densidade aparente), enquanto DD2 e DD3 foram menos adequados devido às suas propriedades inferiores causadas pela presença de impurezas que devem ser removidas.

Palavras-chave: Djebel Debbagh caulim, isolantes elétricos, rigidez dielétrica, resistência à flexão.

\section{INTRODUCTION}

Kaolin is a commercial term used to describe white clay composed essentially of kaolinite with a general formula: $\mathrm{Al}_{4} \mathrm{Si}_{4} \mathrm{O}_{10}(\mathrm{OH})_{8}$. Kaolins are distinguished from other clays by whiteness, and fine controllable particle size [1]. Kaolin consists of one tetrahedral silica sheet and one octahedral alumina sheet; it is an important industrial raw material having widespread applications in industries such as the manufacture of papers, paints, rubbers, ceramics, cosmetics, plastic and medicines [2-4]. The choice of kaolin for industrial applications is dependent on several factors including specific requirements for developing a particular technology [5]. Mineralogically and chemically, kaolin contains quartz as the major impurity and iron (in form of $\mathrm{Fe}_{2} \mathrm{O}_{3}$ ) and titania (in the form of anatase) as minor impurities [6-8]. The

*m.laraba@univ-tebessa.dz.

(D) https://orcid.org/0000-0003-1479-7092 presence of impurities, particularly iron and titania bearing minerals, impacts color to kaolin (low brightness) and are detrimental in most kaolin applications.

Most of the recent studies conducted on Djebel Debbagh kaolin deposit has focused on the understanding of thermal behavior of different phases and the use of this kaolin as a raw material for the refractory industry [9-15]. Contrarily to this, studies on the utilization as a raw material that can be used in the electrical insulator industry are rare. The DD1 kaolin has the highest properties (whiteness, brightness, purity), but DD2 and DD3 kaolins have lower properties and cannot be used in whiteware production due to their colors (grey and blackish, respectively).

The objective of this study was to characterize three types of kaolin from Djebel Debbagh deposit (DD1, DD2 and DD3) in order to be used in electrical porcelain insulators as local raw material. The physical and chemical properties of kaolin are essential before considering it as a basic raw material in electrical insulators. To characterize 
these three kaolins, X-ray fluorescence, X-ray diffraction, scanning electron microscopy, differential thermal analysis and thermogravimetric analysis were carried out. For the insulator tests, dielectric strength, bending strength and bulk density were performed.

\section{MATERIALS AND METHODS}

Sample preparation: three samples of kaolin (DD1, DD2 and DD3) were collected from Djebel Debbagh deposit located in the East of Algeria for this investigation. To prepare the fine powders, each sample was milled with a milling machine (Retsch, RS 100) during $15 \mathrm{~s}$ and sieved to obtain three fractions less than $63 \mu \mathrm{m}$ for the characterization.

Formulation of electrical insulators: an electrical insulator is a dielectric material that has poor conduction of electricity, but an efficient supporter of electrostatic fields. Clays such as ball clay and/or kaolin are used as an essential raw material for the porcelain insulator. The major function of these ceramic porcelain insulators is to provide insulation from electricity. The main constituents of electrical porcelain bodies are clays (as plastic materials), silica and alumina (as fillers) and feldspars which act as a flux material [16]. The dielectric constant $\left(\varepsilon^{\prime}\right)$ and the dielectric loss $(\tan \delta)$ are important electrical properties of the porcelain insulator [17]. The initial compositions and particle/grain-sizes of the three raw materials are reported in Table I. The base composition for making electrical porcelain insulators was prepared using (in weight) $50 \%$ of kaolin, $30 \%$ of feldspar and $20 \%$ of silica for each porcelain formulation (P1, P2 and $\mathrm{P} 3)$. Feldspar and silica raw materials were provided from Société des Feldspaths d'Algérie, Spa, SOFELD and Société Algérienne des Granulats, Spa ALGRAN, respectively.

Table I - Used compositions and grain-size of the raw materials.

[Tabela I - Composições utilizadas e granulometria das matérias-primas.]

\begin{tabular}{cccc}
\hline Raw material & Kaolin (\%) & Feldspar (\%) & Silica (\%) \\
\hline P1 & DD1: 50 & 30 & 20 \\
P2 & DD2: 50 & 30 & 20 \\
P3 & DD3: 50 & 30 & 20 \\
Grain-size & $150 \mu \mathrm{m}$ & $100 \mu \mathrm{m}$ & $80 \mu \mathrm{m}$ \\
\hline
\end{tabular}

To dry and to make good sieving, all raw materials were introduced in an oven at $110{ }^{\circ} \mathrm{C}$ during $24 \mathrm{~h}$. After that, the dried raw materials of kaolin, feldspar and silica were sieved to obtain the following grain-sizes: $<150,<100$ and $<80 \mu \mathrm{m}$, respectively. After these operations, kaolin, feldspar and silica were mixed using an agate for a sufficient time to get homogenous compositions. As a binder, the polyvinyl alcohol (PVA) was added with the raw materials. To obtain 3 pellets with $20 \mathrm{~mm}$ of diameter and $3 \mathrm{~mm}$ of thickness, the formulations (P1, P2 and P3) were formed in a hydraulic press at $140 \mathrm{MPa}$. Afterward, the three pellets were heated using a rate of $5^{\circ} \mathrm{C} / \mathrm{min}$ up to $1250{ }^{\circ} \mathrm{C}$ and sintered during $2 \mathrm{~h}$. Firing beyond this temperature results in progressive deterioration of the properties of the samples, causing deterioration of both bending and dielectric strengths. Firing above this sintering temperature also reduces the strength due to a reduction in quartz and an increase in glass phase [18].

Testing methods of electrical insulators: three parallelepiped samples $(200 \times 20 \times 10 \mathrm{~mm})$ were prepared with the same formulated compositions cited in Table I. To perform the bending strength tests, Netzsch dynamometer (401/3) was used according to the ASTM C674-13 standard. The bending strength of samples was measured by threepoint flexure, where each sample was placed between two supports with a loading force applied at the middle. The formula used to calculate the bending strength, $\mathrm{M}(\mathrm{MPa})$, is as follows:

$$
\mathrm{M}=\frac{3 \mathrm{PL}}{2 \mathrm{bd}^{2}}
$$

where $\mathrm{P}$ is the load at rupture $(\mathrm{N}), \mathrm{L}$ distance between supports $(\mathrm{mm}), \mathrm{b}$ width of the specimen $(\mathrm{mm})$, and $\mathrm{d}$ thickness of specimen $(\mathrm{mm})$. The dielectric strength tests were performed according to the ASTM D-149 standard with the short-time method. The pellets $(20 \mathrm{~mm}$ of diameter and $3 \mathrm{~mm}$ of thickness) were placed between two electrodes and introduced in a container filled with oil; afterward, a high voltage was gradually applied on the pellets until the voltage dropped on the voltmeter (breakdown voltage). The bulk density was measured according to ASTM C-373 standard based on the measurement of the volumes. Eq. B was used to calculate the bulk density $\left(\mathrm{g} / \mathrm{cm}^{3}\right)$ of the sintered pellets:

$$
\text { Bulk density }=\frac{(\mathrm{Wd} x \mathrm{Dw})}{(\mathrm{Ds}-\mathrm{Wsp})}
$$

where Wd is dry weight, Dw density of water, Wsp suspended immersed weight, and Ws soaked weight.

Grain-size analysis: in order to obtain fine powders for the grain-size analysis, the three samples were crushed with a crusher (Retsch, BB 100 Mangane) and milled with a ball mill (Ortoalresa). Each powder sample $(\sim 540 \mathrm{~g})$ was sieved by 7 normalized sieves (DIN-ISO 3310/1) to obtain the fractions of (>1000, 1000-500, 500-250, 250-125, 125-75, $75-50,50-25$, and $<25 \mu \mathrm{m}$ ) using a vibratory machine (Retsch, AS 200). The amplitude was 1.50 and the sieving time was $10 \mathrm{~min}$ for each sample. $X$-ray fluorescence analysis $(X R F)$ : the average chemical compositions of kaolin samples were analyzed using Thermo Niton XL3t XRF analyzer. Scanning electron microscopy (SEM): the three sample morphologies were observed by scanning electron microscopes equipped with EDX analyzer: Jeol, JSM 6610-LV, equipped with Inca Energy 350 microanalyzer, and Jeol, JSM-5600, equipped with an Oxford Inca Energy 200 microanalyzer. X-ray diffraction (XRD) analysis: XRD analysis was performed to identify different mineral phases present in the three samples. The used machine was a Philips system, X'Pert MPD, with 
a configuration of $40 \mathrm{~mA}$ and $45 \mathrm{kV}$. These recordings were

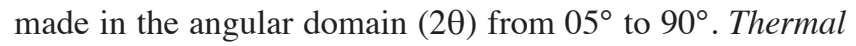
analysis: thermogravimetry (TG) and differential thermal analysis (DTA) were simultaneously conducted on the three powder samples using a thermal analyzer (Mettler Toledo, TGA/SDTA851e) at atmospheric conditions. The samples were heated at a maximum temperature of $1200{ }^{\circ} \mathrm{C}$ with a rate of $10^{\circ} \mathrm{C} / \mathrm{min}$.

\section{RESULTS AND DISCUSSION}

Grain-sizes analysis: the primary function of precision particle analysis is to obtain quantitative data about the size and size distribution of particles in the material [19, 20]. The grain-size results of the three samples (DD1, DD2 and DD3) are listed in Table II. The results revealed that the three samples of kaolin were closely similar; it can be concluded that they had the same grain-size distribution, which presented trimodal distributions constituted by three fractions: i) for DD1, the first fraction of $50 \mu \mathrm{m}$ with about $10 \%$ in mass, the second fraction of average size of $180 \mu \mathrm{m}$ with $60 \%$, and the third fraction of $900 \mu \mathrm{m}$ with about $90 \%$; and ii) for DD2 and DD3 samples, they were more similar and had more coarse particles than DD1; the first fraction of $75 \mu \mathrm{m}$ with about $10 \%$, the second fraction of $250 \mu \mathrm{m}$ with
$60 \%$, and the third fraction of $950 \mu \mathrm{m}$ with $90 \%$.

$X$-ray fluorescence (XRF) analysis: the method of elemental analysis of clays has continuously shown the class of aluminosilicates to which the analyzed material corresponds [21]. The obtained results of the chemical analysis are listed in Table III. The chemical elements such as Al and Si found in the EDX analyses of the two samples were in line with the results found in the chemical analyzes by XRF. The silica contents in the three samples were approximately similar $(44.27 \%, 38.18 \%$ and $39.70 \%)$ and the alumina contents were $37.94 \%, 39.30 \%$ and $34,67 \%$ for DD1, DD2 and DD3, respectively. The $\mathrm{SiO}_{2} / \mathrm{Al}_{2} \mathrm{O}_{3}$ ratio of the three samples was equal to $1.16,0.97$ and 1.14 , which were very close to pure kaolinite. The contents of $\mathrm{MgO}, \mathrm{CaO}, \mathrm{Na}_{2} \mathrm{O}, \mathrm{K}_{2} \mathrm{O}$ and $\mathrm{P}_{2} \mathrm{O}_{5}$ were low in the samples. However, the low content of $\mathrm{Fe}_{2} \mathrm{O}_{3}$ and the total absence of $\mathrm{TiO}_{2}$ make the Djebel Debbagh kaolin very attractive raw material for several industries. The presence of $\mathrm{MnO}$ in DD2 and DD3 samples $(0.18 \%$ and $0.48 \%$, respectively) gave them gray and blackish color, decreasing their brightness and whiteness.

SEM-EDX analysis: scanning electron microscopy (SEM) of kaolin samples allowed the determination of their particle shapes and sizes, as well as the mineralogical components. SEM produces a two-dimensional (2-D) raster

Table II - Grain-size distribution of the three kaolins.

[Tabela II - Distribuição granulométrica dos três caulins.]

\begin{tabular}{cccccccccc}
\hline $\begin{array}{c}\text { Size } \\
\text { range } \\
(\mu \mathrm{m})\end{array}$ & $\begin{array}{c}\text { Weight } \\
(\mathrm{g})\end{array}$ & $\begin{array}{c}\text { Deight } \\
(\%)\end{array}$ & $\begin{array}{c}\text { Cumulative } \\
\text { passing }(\%)\end{array}$ & $\begin{array}{c}\text { Weight } \\
(\mathrm{g})\end{array}$ & $\begin{array}{c}\text { Deight } \\
(\%)\end{array}$ & $\begin{array}{c}\text { Cumulative } \\
\text { passing }(\%)\end{array}$ & $\begin{array}{c}\text { Weight } \\
(\mathrm{g})\end{array}$ & $\begin{array}{c}\text { Weight } \\
(\%)\end{array}$ & $\begin{array}{c}\text { Cumulative } \\
\text { passing }(\%)\end{array}$ \\
\hline$>1000$ & 18.53 & 3.43 & 96.57 & 32.67 & 6.01 & 93.99 & 27.4 & 5.08 & 94.92 \\
$1000 / 500$ & 101.42 & 18.79 & 77.78 & 134.89 & 24.83 & 69.16 & 139.9 & 25.92 & 69.01 \\
$500 / 250$ & 120.75 & 22.37 & 55.41 & 137.32 & 25.28 & 43.88 & 135.9 & 25.18 & 43.83 \\
$250 / 125$ & 106.00 & 19.64 & 35.77 & 88.50 & 16.29 & 27.59 & 94.9 & 17.58 & 26.25 \\
$125 / 100$ & 48.06 & 8.90 & 26.86 & 27.75 & 5.11 & 22.48 & 26 & 4.82 & 21.43 \\
$100 / 75$ & 51.52 & 9.54 & 17.32 & 41.14 & 7.57 & 14.91 & 34.3 & 6.35 & 15.08 \\
$75 / 50$ & 34.83 & 6.45 & 10.87 & 28.83 & 5.31 & 9.60 & 26.3 & 4.87 & 10.21 \\
$50 / 25$ & 43.85 & 8.12 & 2.74 & 45.41 & 8.36 & 1.24 & 51.4 & 9.52 & 0.69 \\
$<25$ & 14.80 & 2.74 & 0 & 6.75 & 1.24 & 0 & 3.7 & 0.69 & 0 \\
Total & 539.76 & 100 & - & 543.26 & 100 & - & 539.80 & 100 & - \\
\hline
\end{tabular}

Table III - Chemical composition (wt $\%$ ) of raw materials used.

[Tabela III - Composição química (\% em massa) das matérias-primas utilizadas.]

\begin{tabular}{cccccccccccc}
\hline Sample & $\mathrm{SiO}_{2}$ & $\mathrm{Al}_{2} \mathrm{O}_{3}$ & $\mathrm{Fe}_{2} \mathrm{O}_{3}$ & $\mathrm{MnO}$ & $\mathrm{MgO}$ & $\mathrm{CaO}$ & $\mathrm{Na}_{2} \mathrm{O}$ & $\mathrm{K}_{2} \mathrm{O}$ & $\mathrm{TiO}_{2}$ & $\mathrm{P}_{2} \mathrm{O}_{5}$ & $\mathrm{LOI}$ \\
\hline $\mathrm{DD} 1$ & 44.27 & 37.94 & 0.12 & 0 & 0.13 & 0.15 & 0.14 & 0.02 & 0 & 0.01 & 16.98 \\
$\mathrm{DD} 2$ & 38.18 & 39.30 & 0.19 & 0.18 & 0.13 & 0.21 & 0.10 & 0.01 & 0 & 0.01 & 21.25 \\
$\mathrm{DD} 3$ & 39.70 & 34.67 & 0.28 & 0.48 & 0.16 & 0.39 & 0.13 & 0.01 & 0 & 0.02 & 24.18 \\
Feldspar & 66.37 & 19.53 & 0.46 & 0.03 & 0.05 & 0.13 & 1.32 & 10.93 & 0.02 & 0.04 & 0.70 \\
Silica & 98.39 & 1.24 & 0.13 & 0 & 0.04 & 0.09 & 0.03 & 0.08 & 0.11 & 0.01 & 0.30 \\
\hline LOI - loss on ignition at 1000 & & & \\
\end{tabular}

LOI - loss on ignition at $1000^{\circ} \mathrm{C}$. 
image by bombarding the surface of a sample with a beam of electrons and then detecting the various signals produced by the interaction between sample and electron beam [22, 23]. Energy dispersive X-ray spectroscopy (EDX) is commonly used to provide more specific data on the elemental composition of a specific point or within a certain area of a sample [24]. SEM-EDX results are shown in Figs. 1 to 3. The SEM micrograph of DD1 (Fig. 1) showed that the sample was pure kaolin and mainly composed of alumina and silica. $\mathrm{Na}, \mathrm{Ba}$ and $\mathrm{Ca}$ were present in very small amounts (EDX-3). $\mathrm{MnO}$ was not detected in this sample. EDX analysis of DD2 (Fig. 2) indicated the presence of a significant proportions of aluminum and silicon as components of microcrystalline quartz, which was rough and with angular shapes, in EDX-1 and microanalysis of the kaolin in EDX-2. The Fe, Mn and Ca were present in EDX-3 spectrum. The SEM micrograph of DD3 (Fig. 3a) revealed that the darkest component is predominantly kaolin with irregular shapes. The disperse most reflective compounds were Mn-oxide. Kaolin was analyzed in EDX-1 and the opaque was analyzed in EDX2. The Mn-oxide had minor quantities of $\mathrm{Co}$ and Ni. The
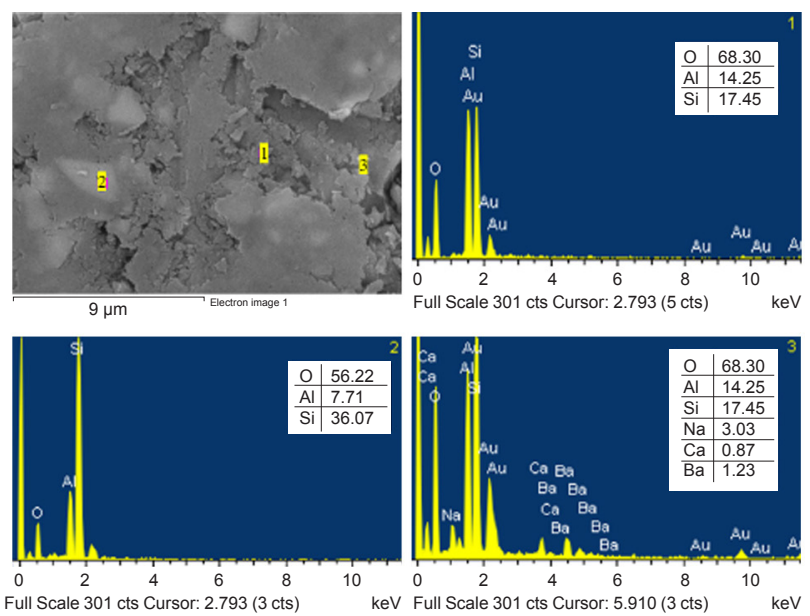

Full Scale 301 cts Cursor: 2.793 (3 cts) keV Full Sc

[Figura 1: MEV-EDX do caulim DD1.]
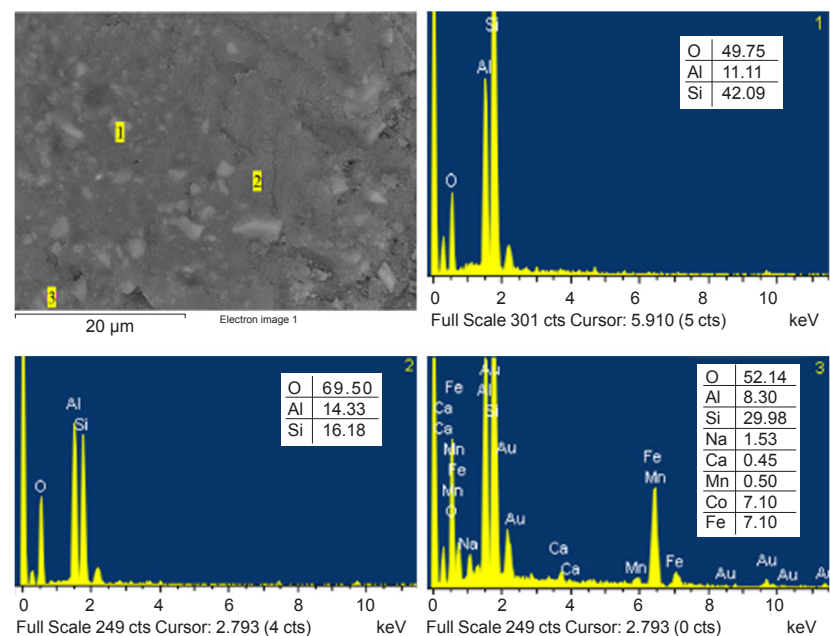

Figure 2: SEM-EDX of DD2 kaolin.

[Figura 2: MEV-EDX do caulim DD2.]
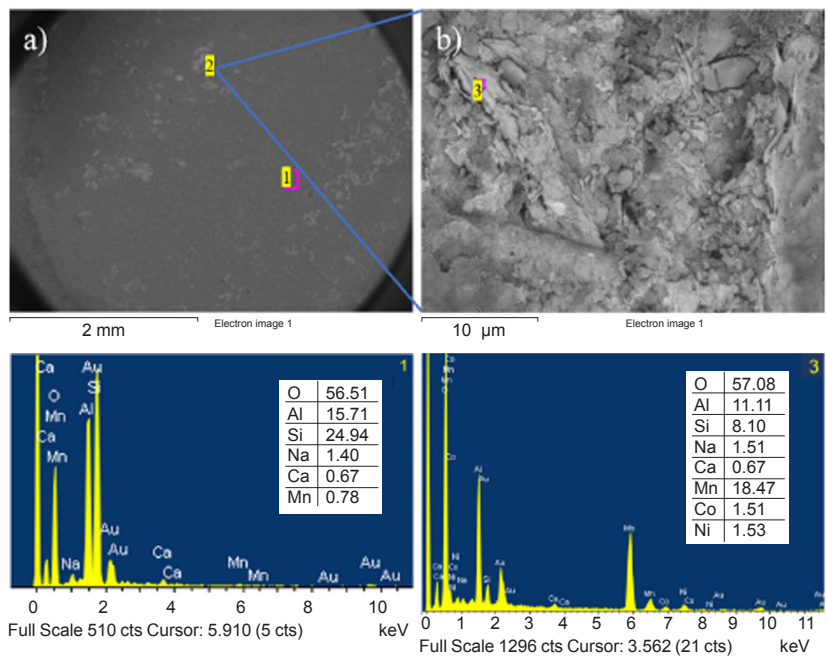

Figure 3: SEM-EDX of DD3 sample.

[Figura 3: MEV-EDX do caulim DD3.]

detailed EDX of the Mn-oxide component (Fig. 3b) showed that it is very closely linked to kaolin. All the measured analyses by SEM-EDX for the two samples of kaolin (DD2 and DD3) were constituted by $\mathrm{Al}, \mathrm{Si}, \mathrm{Fe}, \mathrm{Mn}, \mathrm{Na}, \mathrm{Ca}, \mathrm{K}$ and $\mathrm{O}$, which were confirmed by the chemical analysis cited in Table II with oxides: $\mathrm{Al}_{2} \mathrm{O}_{3}, \mathrm{SiO}_{2}, \mathrm{Fe}_{2} \mathrm{O}_{3}, \mathrm{MnO}, \mathrm{Na}_{2} \mathrm{O}, \mathrm{CaO}$ and $\mathrm{K}_{2} \mathrm{O}$.

$X$-ray diffraction analysis (XRD): XRD technique is widely used to identify whole rock mineralogy and clay mineralogy through the interaction of the X-ray beam with a sample. The method is based on identifying the pattern of basal peaks and their corresponding relative intensity values occurring in the X-ray diffraction pattern $[25,26]$. The obtained results of XRD of the three kaolin samples in the $2 \theta$ range of $5^{\circ}$ to $90^{\circ}$ are shown in Table IV and Fig. 4. The XRD pattern of DD1 essentially illustrated the characteristic peaks attributable to kaolinite and/or halloysite and quartz. By comparison, DD2 and DD3 XRD patterns were similar; these samples had the majority of reflection peaks attributable to kaolinite ( $\mathrm{d}=7.47$ and $7.79 \AA$, respectively); vermiculite was indicated in the reference patterns. The peak at $d=9.49 \AA$ in DD3 sample indicated the presence of halloysite. Some small peaks indicated the presence of low proportions of hematite and manganese oxide. These results were in line with the chemical analysis mentioned in Table III. The presence of manganese oxide had an effect on the quality of the two samples, resulting in the color of DD2 and DD3 as blackish and gray, respectively.

Thermal analysis (TG-DTA): during the heat treatment, kaolinite undergoes a number of thermal phenomena that are: the exothermic peak observed around $200{ }^{\circ} \mathrm{C}$ is due to the release of additional water absorbed. The endothermic peak observed around $600{ }^{\circ} \mathrm{C}$ is characteristic of dehydroxylation of kaolinite. This is the departure of the structural water and the formation of an amorphous material called metakaolin $[27,28]$. The transformation associated with the exothermic peak observed around $1000{ }^{\circ} \mathrm{C}$ is still the subject of many studies. This is the exothermic transformation within the 
Table IV - Corresponding mineral phases of DD1, DD2 and DD3.

[Tabela IV - Fases minerais correspondentes de DD1, DD2 e DD3.]

\begin{tabular}{cccccc}
\hline Sample & Ref. code & Score & Compound & Scale factor & Chemical formula \\
\hline DD1 & $01-080-0886$ & 35 & Kaolinite 1VTAVRG & 1.074 & $\mathrm{Al}_{2}\left(\mathrm{Si}_{2} \mathrm{O}_{5}\right)(\mathrm{OH})_{4}$ \\
& $00-006-0221$ & 7 & Kaolinite 1Md & 0.181 & $\mathrm{Al}_{2} \mathrm{Si}_{2} \mathrm{O}_{5}(\mathrm{OH})_{4}$ \\
DD2 & $00-034-0166$ & 2 & Vermiculite-2VTMNRG & 0.975 & $(\mathrm{Mg}, \mathrm{Al})_{3}\left(\mathrm{Si}_{3}, \mathrm{Al}\right)_{4} \mathrm{O}_{10}(\mathrm{OH})_{2} \cdot 4 \mathrm{H}_{2} \mathrm{O}$ \\
& $00-006-0221$ & 13 & Kaolinite 1Md & 0.161 & $\mathrm{Al}_{2} \mathrm{Si}_{2} \mathrm{O}_{5}(\mathrm{OH})_{4}$ \\
\multirow{2}{*}{ DD3 } & $00-034-0166$ & 6 & Vermiculite-2VTMVG & 0.433 & $(\mathrm{Mg}, \mathrm{Al})_{3}\left(\mathrm{Si}_{2}, \mathrm{Al}\right)_{4} \mathrm{O}_{10}(\mathrm{OH})_{2} \cdot 4 \mathrm{H}_{2} \mathrm{O}$ \\
\hline
\end{tabular}
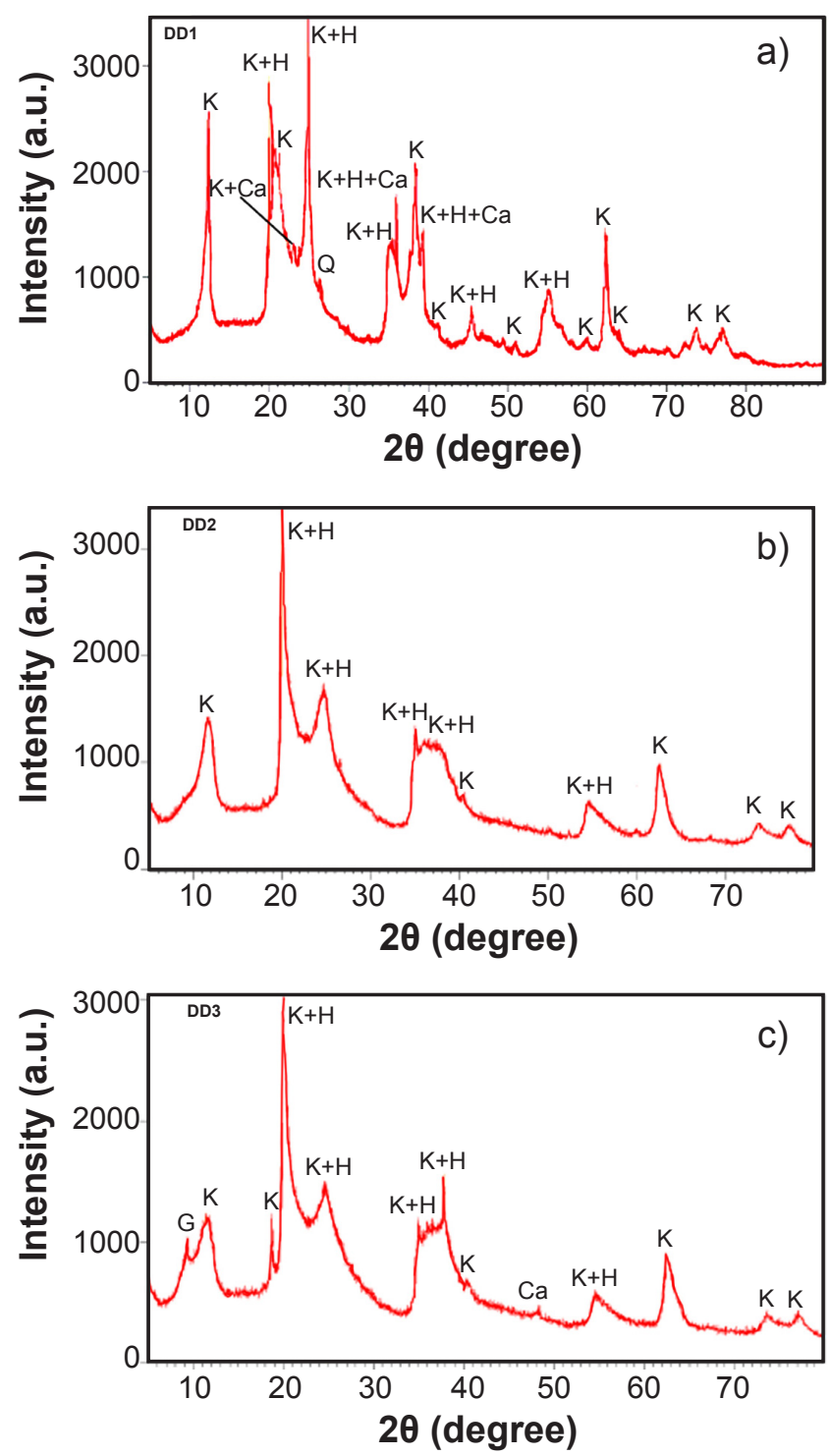

Figure 4: XRD patterns of the three kaolins (K: kaolinite, $\mathrm{H}$ : halloysite, Ca: calcite, G: gibbsite, Q: quartz).

[Figura 4: Padrões de DRX dos três caulins (K: caulinita, $H$ : haloisita, Ca: calcita, G: gibbsita, Q: quartzo).]

metakaolin to give the mullite (aluminum-rich phase) called primary mullite with the appearance of an intermediate phase of the spinel structure. Thermal analysis (DTA and TG) of the three kaolins are shown in Fig. 5. Regarding the DTA curves, the observed endothermic peaks at about $540{ }^{\circ} \mathrm{C}$ corresponded

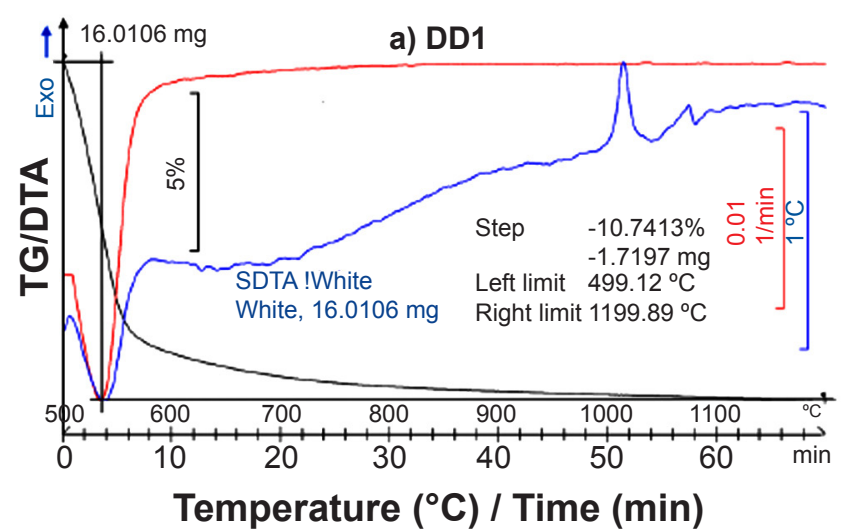

b) DD2
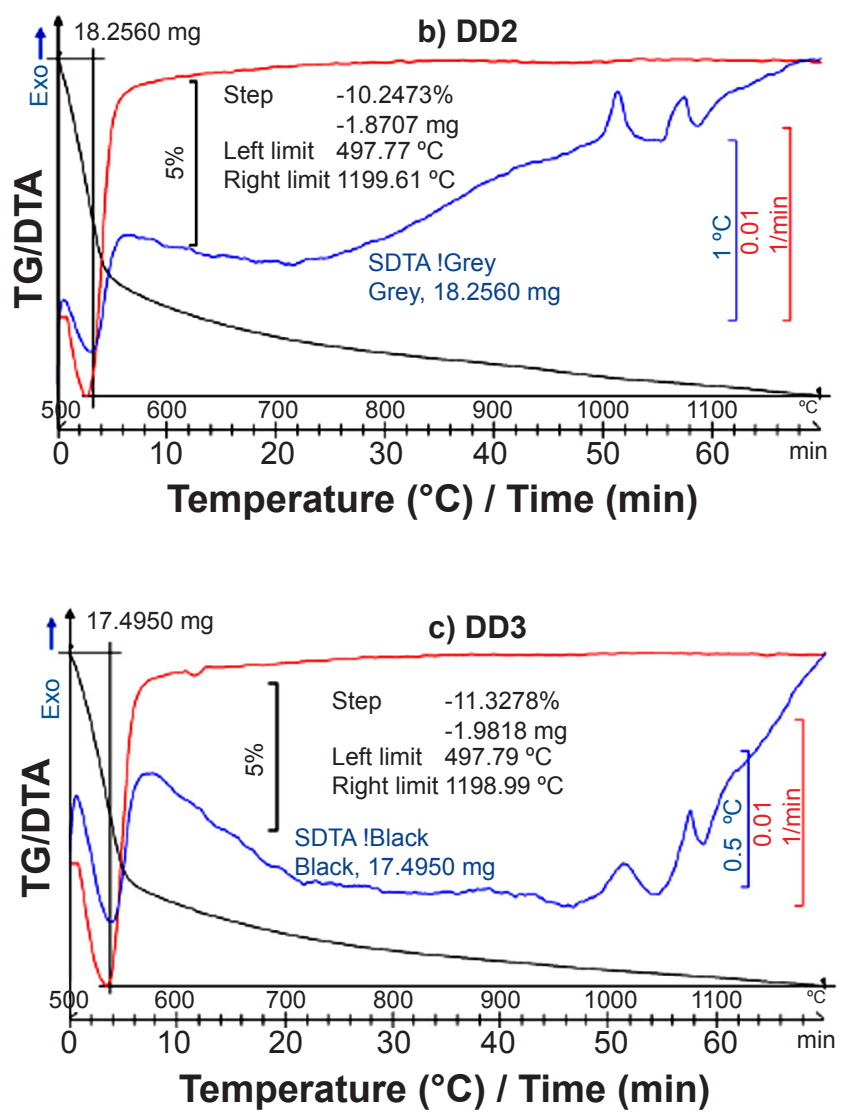

Figure 5: TG-DTA curves of the three samples of kaolin (DD1, DD2 and DD3).

[Figura 5: Curvas de TG-DTA das três amostras de caulim (DD1, DD2 e DD3).] 
to the dehydroxylation of kaolinite. No exothermic event indicating the formation of new crystalline phases occurred below $1000{ }^{\circ} \mathrm{C}$ [29]. The exothermic peak around $1020{ }^{\circ} \mathrm{C}$ for the three samples indicated the recrystallization of the metakaolin. These results were in line with that obtained by chemical and mineralogical analysis of each sample which consisted mainly of kaolinite and quartz. The well-ordered sample has its decomposition peak temperature at a quite high value $\left(\mathrm{T}_{\mathrm{d}}>571{ }^{\circ} \mathrm{C}\right)$; ordered sample has its decomposition peak temperature $\mathrm{T}_{\mathrm{d}}$ at the interval $561-570^{\circ} \mathrm{C}$. For a poorly ordered sample, the temperature decomposition varies from 546 to $560{ }^{\circ} \mathrm{C}$ and disordered sample decomposes at temperatures up to $545^{\circ} \mathrm{C}[30]$. According to the obtained results of DTA, the decomposition temperature of DD1, $\mathrm{DD} 2$ and DD3 was less than $545{ }^{\circ} \mathrm{C}$ that indicated the poor orderliness of the three samples. The TG curves showed that the weight losses of DD1, DD2 and DD3 samples were about $15 \%, 18.5 \%$ and $23 \%$, respectively, which corresponded to the endothermic peaks at $\sim 540{ }^{\circ} \mathrm{C}$ for each sample. These weight losses in the TG analysis were closes to the corresponding LOI listed in Table II.

Dielectric strength tests: dielectric characteristics of ceramic materials are of increasing importance due to their various applications in the field of solid-state electronics. The main applications of ceramic dielectrics are as capacitive elements in electronic circuits and electrical insulators. The obtained results of dielectric strength tests revealed that the formulation P1 consisting of 50\% kaolin, 30\% feldspar, and 20\% quartz had the highest dielectric strength $(\sim 18.34 \mathrm{kV} / \mathrm{mm})$ at the sintering temperature of $1250{ }^{\circ} \mathrm{C}$; this confirmed the kaolin DD1 was the more suitable kaolin as raw material to produce an electric porcelain insulator. The formulations P2 and P3 had a lower dielectric strength (12.53 and $10.72 \mathrm{kV} / \mathrm{mm}$, respectively); these values were caused by the presence of $\mathrm{MnO}$ and $\mathrm{Fe}_{2} \mathrm{O}_{3}$ which can be removed by an enrichment process. The dielectric strength results of the three formulations are shown in Fig. 6a.

Bending strength (modulus of rupture) tests: the results showed that the P1 formulation had the highest bending strength value $(\sim 83.2 \mathrm{MPa})$ sintered at $1250{ }^{\circ} \mathrm{C}$ that can be due to the presence of quartz and to the low porosity index, while P1 and P2 had lower bending strength ( $\sim 53.4$ and $\sim 45.8 \mathrm{MPa}$, respectively) which indicated the low presence of quartz. The measured values of bending strength are shown in Fig. $6 b$.

Bulk density tests: the bulk density results of the three formulations are represented in Fig. 6c. It was found that the bulk densities were highest at the sintering temperature of $1250{ }^{\circ} \mathrm{C}$. The bulk densities were $\sim 2.81, \sim 2.53$ and $\sim 2.44$ $\mathrm{g} / \mathrm{cm}^{3}$ for P1, P2 and P3, respectively; these values were in line with the obtained values of dielectric and bending strengths for the same formulations. These results confirmed that when the bulk density is high the dielectric strength and the flexural strength become high. The curves of the three formulations can be divided into two parts. The first part from 1100 to $1250{ }^{\circ} \mathrm{C}$, which indicated the increasing of bulk densities, was the mullitization stage; the second part
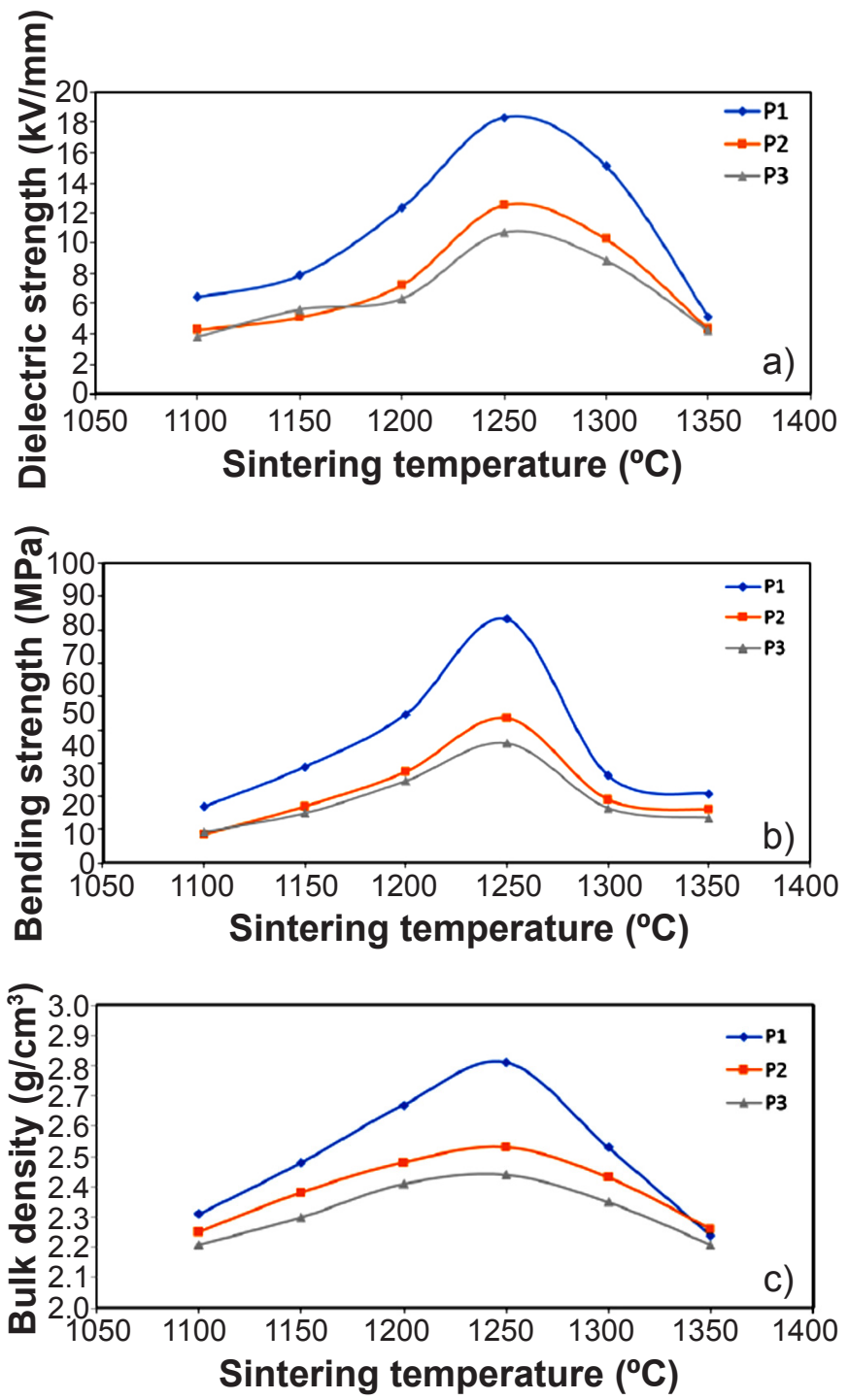

Figure 6: Dielectric strength (a), bending strength (b), and bulk density (c) of P1, P2 and P3 formulations.

[Figura 6: Resistência dielétrica (a), resistência à flexão (b) e densidade aparente (c) das formulações de P1, P2 e P3.]

from 1250 to $1350{ }^{\circ} \mathrm{C}$, which indicated the decreasing of bulk densities of the samples, can be recrystallization of the first mullite. From the obtained results, it can be concluded that $1250^{\circ} \mathrm{C}$ is the optimal temperature to reach the highest densification of porcelains $\mathrm{P} 1, \mathrm{P} 2$ and $\mathrm{P} 3$.

\section{CONCLUSIONS}

In this study, three types of kaolin were investigated for their utilizations in electrical porcelain insulators. The characterization results showed that all kaolin samples had almost similar chemical compositions. Kaolinite and halloysite were the major components with variable proportions of $\mathrm{Fe}_{2} \mathrm{O}_{3}$ and $\mathrm{MnO}$ considered as impurities. The composition of porcelain formulations consisted in weight of $50 \%$ kaolin, $30 \%$ feldspar, and $20 \%$ quartz. From the results of electrical and mechanical properties of the three porcelains prepared with three different kaolins, it can be 
conducted to produce electrical insulators from the local raw materials (kaolin, feldspar and silica). The total absence of manganese and low iron content in DD1 kaolin in its raw form make the best raw material for making high-voltage electrical porcelain (P1). The DD2 and DD3 samples were suitable for the production of electrical porcelain (P2 and P3) with lower electrical and mechanical properties compared to $\mathrm{P} 1$; this can be due to the presence of $\mathrm{MnO}$ and $\mathrm{Fe}_{2} \mathrm{O}_{3}$ impurities that can be treated by a special process to eliminate them. From the obtained results, it can also be concluded that the sintering temperature of $1250{ }^{\circ} \mathrm{C}$ during $2 \mathrm{~h}$ is the optimal temperature to reach the highest electrical and mechanical properties of porcelains P1, P2 and P3. Above this temperature, the porcelains can be deteriorated due to the increase of porosity.

\section{ACKNOWLEDGMENTS}

With much pleasure, I want to appreciate my sincere thanks to Prof. Abdelmalek Roula in the Process Engineering Departments, LIME Laboratory, University of Jijel, Algeria for its precious help. I extend my sincere thanks to Dr. Rodrigo Alvares Garcia and Dr. Francisco Javier Iglesias Rodríguez, in the School of Mining, Energy and Materials Engineering of Oviedo for their help and providing of characterizations equipment at Metallogeny laboratory.

\section{REFERENCES}

[1] A.J. Bloodworth, D.E. Highley, C.J. Mitchell, "Ind. Miner. Lab. manual: kaolin", Techn. Rep. WG/93/1, Br. Geol. Survey, UK (1993) 1.

[2] C.C. Harvey, H.H. Murray, Appl. Clay Sci. 11 (1997) 285.

[3] H.H. Murray, Clay Miner. 34 (1999) 39.

[4] H.H. Murray, Appl. Clay Sci. 17 (2000) 207.

[5] C. Nkoumbou, A. Njoya, D. Njoya, C. Grosbois, D. Njopwouo, J. Yvon, F. Martin, Appl. Clay Sci. 43 (2009) 118.

[6] W.M. Carty, U. Senapati, J. Am. Ceram. Soc. 81, 1 (1998) 3.

[7] H.H. Murray, W.D. Keller, in "Kaolin genesis and utilization", H. Murray, W. Bundy, C. Harvey (Eds.), Clay Miner. Soc. Colorado, USA (1993) 1.

[8] P.G. Pinheiro, J.D. Fabris, W.N. Mussel, E. Murad, R.B. Scorzelli, V.K. Garg, J. South Am. Earth Sci. 20 (2005) 267. [9] B. Amrane, E. Ouedraogo, B. Mamen, S. Djaknoun, N. Mesrati, Ceram. Int. 37 (2011) 3217.

[10] O. Castellin, "Influence de la vitesse de traitement thermique sur le comportement d'un kaolin : application au frittage rapide", Thèse, Un. Limoges (2000).

[11] M. Kolli, M. Hamidouche, G. Fantozzi, J. Chevalier, Ceram. Int. 33 (2007) 1435.

[12] B. Rabehi, "Evaluation des propriétés réfractaires et cimentaires du kaolin de Djebel Debbagh", PhD Thesis, Un. M'Hamed Bougara-Boumerdes, Algeria (2013).

[13] S. Ladjama, A. Grid, N. Touati, A. Meberek, H. Rezzag, S. Bouchoucha, in $3^{\mathrm{ème}}$ Conf. Int. Mécan., Annaba (2017).

[14] N.S. Soro, "Influence des ions de fer sur les transformations thermiques de la kaolinite", Thèse, Un. Limoges (2003) 34.

[15] Z. Belamri, "Elaboration et caractérisation des matériaux polycristallins à base de kaolin DD et KT2", PhD Thesis, Un. Mentouri-Constantine, Algeria (2008).

[16] S.M. Niraj, K.S. Praveen, T. Pankaj, P. Ram, R.M. Manas, Bol. Soc. Esp. Ceram. V. 57 (2018) 151.

[17] R.H. Piva, P. Vilarinho, M.R. Morelli, M.A. Fiori, O.R.K. Montedo, Ceram. Int. 39 (2013) 7323.

[18] P.W. Olupot, "Assessment of ceramic raw materials in Uganda for electrical porcelain", Lic. Thesis, Royal Inst. Technol. (KTH), Sweden (2006) 11.

[19] C. Bernhardt, Particle size analysis, Chapman Hall, London (1994).

[20] T. Allen, Particle size measurement, $\mathbf{1}, 5^{\text {th }}$ ed., Chapman Hall, London (1997).

[21] W.P. Gates, P.G. Slade, A. Manceau, B. Lanson, Clays Clay Miner. 50, 2 (2002) 223.

[22] G.I. Goldstein, D.E. Newbury, P. Echlin, D.C. Joy, C. Fiori, E. Lifshin, Scanning electron microscopy and X-ray microanalysis, Plenum Press, New York (1981).

[23] L. Reimer, Scanning electron microscopy: physics of image formation and microanalysis, Springer (1998).

[24] R. Rodriguez, D. Crandall, X. Song, C. Verba, D. Soeder, "Imaging techniques for analyzing shale pores and minerals", Dept. Energy, U.S.A. (2014) 28.

[25] A. Sachan, D. Penumadu, J. Geotech. Geol. Eng. 25, 6 (2007) 603.

[26] K. Flogeac, E. Guillon, M. Aplincourt, E. Marceau, L. Stievano, P. Beaunier, Y.M. Frapart, Agron. Sustain. Dev. 25 (2005) 345 .

[27] R. Pampuch, in Proc. IX ${ }^{\text {th }}$ Conf. Silicate Ind., Budapest (1968) 143.

[28] F. Toussaint, J.J. Fripiat, M.C. Gastuche, J. Phys. Chem. 67 (1963) 26.

[29] A. Aboulayt, M. Riahi, M. Ouazzani Touhami, H. Hannache, M. Gomina, R. Moussa, Adv. Powder Technol. 28 (2017) 2393.

[30] L. Vaculíková, E. Plevová, S. Vallová, I. Koutník, Acta Geodyn. Geomater. 8, 1 (2011) 59.

(Rec. 11/08/2018, Rev. 17/10/2018, 13/01/2019, Ac. 16/01/2019) 